UNDERGRADUATE RESEARCH IN NATURAL AND CLINICAL SCIENCE AND TECHNOLOGY (URNCST) JOURNAL Read more URNCST Journal articles and submit your own today at: https://www.urncst.com

\title{
Science Atlantic 2019 Aquaculture \& Fisheries and Biology Conference
}

Zhan Yang, PhD [1]*, Russell H. Easy, PhD [2]

[1] Science Department in Biology, Crandall University, Moncton, New Brunswick, Canada, E1C 9L7

[2] Department of Biology, Acadia University, Wolfville, Nova Scotia, Canada, B4P 2R6

*Corresponding Author: zhan.yang@crandallu.ca

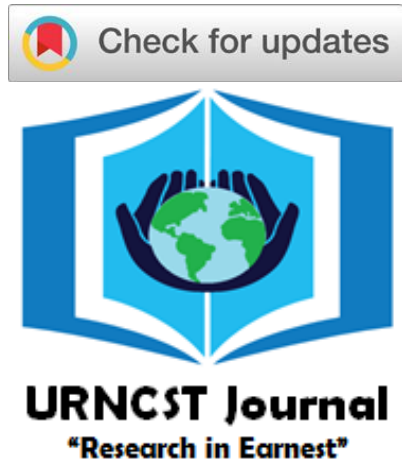

\begin{abstract}
Science Atlantic Aquaculture \& Fisheries and Biology (AF\&B) conference is held annually by the Science Atlantic Biology committee in the conjunction of Aquaculture and Fisheries Committee, which allows undergraduate students to present their results of research. In various research projects, students have chance to make hypotheses on this project, design experiments to accept or deny their hypotheses using real research methods, analyze the data and then draw their conclusions. This particular learning style is vital in post-secondary biology learning, which has been well impregnated in biology programs at all universities in the Maritime. AF\&B conference not only promote this learning style, but also help undergraduates in science communication. Every year, awards are granted to the students giving the best research presentations at annual AF\&B conference. 2019 AF\&B conference was held at Crandall University on March 8th-10th, which attracted science students from 13 universities in all Maritime Provinces of Canada to participate. The following are conference abstracts, which are categorized into three parts: oral presentation in biology, oral presentation in Aquaculture \& Fisheries and poster presentation.
\end{abstract}

Keywords: Aquaculture; fisheries; biology; undergraduates; Maritime; research

Table of Contents

Oral Presentations in Biology

pg. A01-A07

Oral Presentations in Aquaculture \& Fisheries

pg. A08-A12

Poster Presentations in Biology

pg. A12-A21

\section{Conference Abstracts}

Note: These abstracts have been reproduced directly from the material supplied by the authors, without editorial alteration by the staff of the URNCST Journal. Insufficiencies of preparation, grammar, spelling, style, syntax, and usage are the authors.

\section{Oral Presentations in Biology}

Presence of Borrelia bissettii in ticks in Atlantic Canada: A research study Ellice P. Evans, BSc Student [1], Vett Lloyd, PhD [2]

[2] Department of Biology, Mount Allison University, Sackville, New Brunswick, Canada E4L 1E2

[1] Department of Biology, Mount Allison University, Sackville, New Brunswick, Canada E4L 1E2

Introduction: Tickborne pathogens are a significant health risk within Atlantic Canada. Much attention has been paid to Borrelia burgdorferi, the spirochete bacteria most commonly associated with Lyme disease in North America. Comparatively less work has done on other tick and Borrelia species previously found in North America, such as Borrelia bissettii. Borrelia bissettii has been found in scarce abundance in three Ixodes species across Canada. The pathogen has been linked to arthritis symptoms in mice and growing evidence also suggests it is linked to cardiovascular problems. Borrelia bissettii infections in ticks, humans or companion animals could go unnoticed due to species-specific screening assays or presentation with a different set of symptoms

Methods: Genetic screening of Ixodes scapularis from the Mount Allison tick bank was conducted through nested PCR (polymerase chain reaction) targeting sequences from the $23 \mathrm{~S}$ rRNA, OspC, OspA and IGS genes of Borrelia bissettii. Sanger sequencing and nBlast analysis of the NCBI GenBank database was used to confirm the identity of DNA product. 
UNDERGRADUATE RESEARCH IN NATURAL AND CLINICAL SCIENCE AND TECHNOLOGY (URNCST) JOURNAL Read more URNCST Journal articles and submit your own today at: https://www.urncst.com

Results: Borrelia bissettii was sequence confirmed in 5 adult engorged ticks submitted in 2017 from New Brunswick and Nova Scotia.

Conclusion: Borrelia bissettii is present in the Ixodes scapularis of Atlantic Canada in scarce prevalence and may contribute to infection of organisms in the region.

Morphological and molecular characterization of Pricetrema zalophi in marine mammals in Atlantic Canada Caitlyn Gray, BSc Student [1,2,3], Amanda Egers [1,2], Will Robbins [1], Laura Bourque [2,4], Megan Jones [2,4], Robert Hurta [3], Spencer Greenwood [1], Gary Conboy [2]

[1] Department of Biomedical Sciences, Atlantic Veterinary College, University of Prince Edward Island, 550 University Ave., Charlottetown, PE., C1A 4 P3

[2] Department of Pathology and Microbiology, Atlantic Veterinary College, University of Prince Edward Island, 550 University Ave., Charlottetown, PE., C1A 4P3 Atlantic Veterinary College, University of Prince Edward Island, Charlottetown, Prince Edward Island, Canada C1A 4 P3

[3] Department of Biology, University of Prince Edward Island, 550 University Ave., Charlottetown, PE., C1A 4P3

[4] Canadian Wildlife Health Cooperative, Atlantic Veterinary College, Charlottetown, Prince Edward Island, Canada C1A $4 P 3$

Introduction: The trematode parasite Pricetrema zalophi, previously unidentified in Atlantic Canadian waters, was collected from marine mammals. Morphological and molecular characterization was conducted in order to determine whether or not it was identical to the trematode found on the west coast.

Methods: Marine mammals submitted to the Canadian Wildlife Health Cooperative through the AVC Diagnostic Services were necropsied and their gastrointestinal tracts examined for parasites. Following morphological identification of parasites, PCR and DNA sequencing provided confirmatory diagnosis by identifying the closest molecular sequences based on similarity searches (BLAST-Basic Local Alignment Search Tool) in GenBank. Subsequent phylogenetic analysis (MEGA-Molecular Evolutionary Genetic Analysis) revealed relationships to other sequenced parasites providing further support based on sequence affinities.

Results: $P$. zalophi was morphologically identified in 4 individuals across 3 host seal species. Molecular analysis revealed that the fluke recovered in these samples was identical to that found on the West Coast.

Conclusion: This study highlights the value of complementary approaches to diagnosis and the importance of updating databases of parasite prevalence, intensity, host range and geographic distribution.

Docosahexaenoic Acid-Acylated Phloridzin, a novel compound derived from apple phytochemicals and fish oil, inhibits the metabolic activity and proliferation of colon cancer cells in vitro Sarah G. Robertson, BScH Student [1], Wasundara Fernando, PhD [2], H.P.Vasantha Rupasinghe, PhD [2,3], David W. Hoskin, PhD [2,4,5] and Melanie R. Power Coombs, PhD [1]

[1] Department of Biology, Acadia University, Wolfville, NS, Canada, B4P 2R6

[2] Department of Pathology, Dalhousie University, Halifax, Canada, B3H 4R2

[3] Department of Plant, Food, and Environmental Sciences, Dalhousie University, Truro, NS, Canada, B2N 5E3

[4] Department of Microbiology \& Immunology, Dalhousie University, Halifax, NS, Canada, B3H 4R2

[5] Department of Surgery, Dalhousie University, Halifax, NS, Canada, B3H 2 Y9

Phytochemicals are secondary plant metabolites, which have demonstrated anticancer potential. Studies suggest that a diet rich in a variety of fruits and vegetables can result in a decreased cancer risk. The phytochemical phloridzin (PZ), abundant in apples, was esterified with docosahexaenoic acid (DHA) to generate PZ-DHA. Recent studies demonstrated anti-cancer effects of PZ-DHA in experimental models of breast and liver cancers and leukemia. We have examined the anti-cancer effects of PZDHA on HCT-116 and HT-29 colon cancer cells in vitro. A methylthiazolyldiphenyl-tetrazolium bromide (MTT) assay was used to assess the metabolic activity 48 and $72 \mathrm{~h}$ after PZ-DHA treatment. PZ-DHA inhibited the metabolic activity of colon cancer cells in a time- and concentration-dependent manner. Early apoptosis and late apoptosis/necrosis were not significantly increased after $24 \mathrm{~h}$ exposure to $100 \mu \mathrm{M}$ PZ-DHA, as measured by Annexin V/propidium iodide staining. Since high concentrations of PZ-DHA had minimal effects on cell death, cell proliferation was assessed by Oregon Green 488 staining, which indicated that $100 \mu \mathrm{M}$ PZ-DHA significantly inhibited proliferation after $72 \mathrm{~h}$. Our finding that PZ-DHA inhibits the proliferation of HCT-116 colon cancer cells supports further research on the possible treatment of colon cancer using a novel compound derived from food molecules

Yang et al. | URNCST Journal (2019): Volume 3, Issue 4

DOI Link: https://doi.org/10.26685/urnest.142 
UNDERGRADUATE RESEARCH IN NATURAL AND CLINICAL SCIENCE AND TECHNOLOGY (URNCST) JOURNAL Read more URNCST Journal articles and submit your own today at: https://www.urncst.com

Effet de la pression humaine et environnementale sur la sénescence et la reproduction des carcajous (gulo gulo) au Nunavut : A research study

Madeleine Mangoni, Bsc Student in Biology [1], Nicolas Lecomte, PhD [1,2]

[1] Department of Biology, Université de Moncton, Moncton, NB, Canada E1A $3 E 9$

[2] Chaire de recherche du Canada en écologie polaire et boréale, Université de Moncton, Moncton, NB, Canada E1A 3E9

Introduction: Le carcajou (gulo) est un animal important pour les Inuits du Nunavut, autant pour la fourrure que pour la viande. Ces animaux exploités ont subi un déclin de population globalement et sont même disparus du Nouveau-Brunswick. L'étude des facteurs de reproduction et de survie de ces bêtes aidera donc à sa conservation.

Méthodes: En utilisant des méthodes de comptes de cicatrices placentaires nous avons pu déterminer leur effort reproducteur à court terme et le comparer avec les données de sénescence, de parasitisme, de pression humaine, forestière et côtière,

Résultats: On suppose que la reproduction des carcajous devrait augmenter selon le niveau d'âge et cesser de croître, ou diminuer, à un âge plus avancé. Les individus plus près des zones humaines devraient être plus reproducteurs pour contrer la diminution de population causée par la pression humaine. La charge parasitique des individus plus reproducteurs devrait être plus forte, dû à une perte d'energie. Les carcajous près des limites des zones forestières et côtières devraient être plus reproducteurs car il y a plus de ressources dans ces endroits.

Conclusion: Dans le futur, nous souhaitons continuer la recherche sur les carcajous en utilisant les systèmes reproducteurs mâles pour voir s'il y a un effet semblable à ceux trouvés chez les femelles.

The role of iron chelators in reducing lipid peroxidation Amanda N. Nicholson, BSc Student [1], Xu (Shine) Zhang, Co-Supervisor, PhD [2]; Ken Oakes, Co-Supervisor, PhD [1] [1] Department of Biology, Cape Breton University, Sydney, Nova Scotia, Canada BIP 6L2

[2] Verschuren Centre for Sustainability in Energy \& the Environment, Cape Breton University, Sydney, Nova Scotia, Canada B1P $6 L 2$

An increase in labile iron can catalyze the Fenton reaction, which results in formation of ROS (reactive oxygen species) particularly hydroxyl radicals. Hydroxyl radicals generated from Fenton reaction are potent and non-selectively oxidize biomolecules, including lipids. Lipid peroxidation is a chain reaction initiated by the Fenton reaction, which can eventually lead to cell membrane damage and cell death. Chelators can sequester and inactivate iron to prevent Fenton reaction and consequently lipid peroxidation. AA (arachidonic acid) was used to model lipid peroxidation through indirectly detecting one of its end products, malondialdehyde, through its chromogenic reaction with thiobarbituric acid. The model was exposed to Fe3+ and Fenton reaction conditions, i.e., Fe3+ and $\mathrm{H} 2 \mathrm{O} 2$, ROS scavengers, i.e., butylated hydroxytoluene, and iron chelators, i.e., DIBI and deferiprone. The Fenton reaction appears to interfere with the TBARS (thiobarbituric acid reactive substances) assay as the colorimetric dye is bleached when hydrogen peroxide is present. Regardless, Fe3+ alone could induce lipid peroxidation and iron chelator DIBI was most effective at reducing lipid peroxidation. The TBARS assay is not applicable for testing lipid peroxidation by Fenton reagents. In addition, Fe3+ can induce AA peroxidation, and such oxidative damage of the AA model can be suppressed by iron chelators.

Conservation genetics of the endangered plants, Braya longii and $B$. fernaldii (Brassicaceae) Tyra L. Custance, BSc Student [1], Julissa Roncal, PhD [1], Luise Hermanutz, PhD [1]

[1] Department of Biology, Memorial University of Newfoundland, St. John's, Newfoundland, Canada A1B 3 X9

The Limestone Barrens of the Northern Peninsula in Newfoundland, Canada, possess a unique flora that are at risk of extinction due to the extraction of natural resources, climate change, and microbial pathogens. Braya longii and Braya fernaldii (Brassicaceae) are endangered plant species, endemic to the Limestone Barrens. The goal of this study was to use conservation genetics to analyze the genetic diversity and structure of Braya populations to establish management units and help create a genetically diverse seed bank. This study used 5 inter-simple sequence repeats (ISSRs) to obtain 19 loci from a sample of 49 individuals that were collected from 8 populations. Results indicate that the Cape Norman population was the most genetically diverse and the Savage Cove population was the least, across all diversity indexes. An analysis of molecular variance showed significantly higher genetic variation within populations $(65 \%)$ than among $(32 \%),\left(\phi_{\mathrm{sT}}=0.238, P<0.010\right)$. A principal coordinate analysis showed a single cluster of individuals. Based on these results, we recommend that Braya should be managed as a single unit and that stock should be used from each population in future reintroductions, to ensure maximum genetic diversity.

Yang et al. | URNCST Journal (2019): Volume 3, Issue 4

DOI Link: https://doi.org/10.26685/urnest.142 
UNDERGRADUATE RESEARCH IN NATURAL AND CLINICAL SCIENCE AND TECHNOLOGY (URNCST) JOURNAL Read more URNCST Journal articles and submit your own today at: https://www.urncst.com

Differential temporal and sex-linked expression of igf $2 \mathrm{~b}$, atp1a2a, and scn4aa genes and characterization of igf2a and igf2b gene products in the electric organ of the gymnotiform fish Brachyhypopomus gauderio

Victoria J. Ivey, BSc Student [1], Vielka L. Salazar, PhD [2]

[1] Department of Biology, Cape Breton University, Sydney, Nova Scotia, Canada B1P 6L2

[2] Department of Biology, Cape Breton University, Sydney, Nova Scotia, Canada B1P 6L2

The gymnotiform fish Brachyhypopomus gauderio uses its electric organ to generate a weak electric signal for navigation and communication with conspecifics. Electric signal characteristics display sexual dimorphism and circadian rhythmicity, with circadian cycling being more pronounced in males. Electric signal plasticity has been proposed to be regulated by a cellular pathway involving the molecules insulin-like growth factor II (coded by igf $2 a$ and $i g f 2 b$ ), sodium-potassium ATPase (coded by atp1a2a), and voltage-gated sodium channels (coded by scn4aa), but a direct relationship between these molecules has yet to be established in electric fish. This study aimed to identify potential differential expression of these genes among males and females and day and night conditions using normalized expression data from quantitative PCR. One-way ANOVA analysis showed significant differential expression of $\operatorname{scn} 4 a a$ between female day and male night groups, with higher expression in females $(\mathrm{P}-$ Value Tukey $=0.005)$. Further expression analysis is ongoing. This study also aimed to predict the tertiary structures of two isoforms of the insulin-like growth factor II protein and their important functional and conserved regions using predictive modelling software. The results of this study will give further insight into the energetics and cellular mechanisms regulating the plasticity of electrogenic tissues.

Effects of vitamin $B_{12}$ starvation on heat resistance in Fragilariopsis cylindrus Catalina M. Albury, BSc Student [1]

[1] Department of Biology, Dalhousie University, Halifax, NS, Canada B3H4R2

Introduction: Marine microbes play an integral role in global biogeochemical cycles, notably carbon fixation and export. Shifts in temperature and micronutrient concentration may alter the rates of these processes. An improved understanding of microbial nutrient dynamics and their effect on primary productivity is essential for accurate predictions of ocean biogeochemistry in the face of a changing global climate. Past observations of the green temperate algae Chlamydomonas have demonstrated increased heat tolerance related to availability of vitamin $\mathrm{B}_{12}$, which is used to catalyze the production of methionine, an essential amino acid. The primary purpose of the study was to determine how increased temperatures and $\mathrm{B}_{12}$ limitation affect the growth of Fragilariopsis cylindrus, a psychrophilic diatom and key species in polar microbial assemblages.

Methods: In the experiment, Fragilariopsis cultures were exposed to $\mathrm{B}_{12}$ limitation and increased temperatures. Cultures were monitored for heat stress which was characterized by chlorosis, decreased photosynthetic capability, and decreased growth rate. Results: These markers of heat stress were observed in cultures exposed to elevated temperatures, regardless of the availability of $\mathrm{B}_{12}$.

Conclusion: The results of this study indicate that $\mathrm{B}_{12}$ availability may not result in increased temperature tolerance in $\mathrm{F}$. cylindrus, raising questions concerning the differences amongst chomophytes and chlorophytes in the role methionine in heat tolerance.

Effects of inbreeding on fitness in the North Atlantic right whale Sonya N. Radvan, BScH Student [1], Timothy R. Frasier, PhD [1]

[1] Department of Biology, Saint Mary's University, Halifax, Nova Scotia, Canada B3H 3C3

Offspring that are a product of inbreeding often have reduced fitness, known as inbreeding depression. Our understanding of the impact of inbreeding depression in wildlife populations is in its infancy because most studies of inbreeding depression have used captive animals. However, it is suspected that the effects of inbreeding depression are much stronger in the wild. The North Atlantic right whale (Eubalaena glacialis) is the most endangered large whale species that has shown little signs of recovery for the past 70 years. This lack of recovery is due, at least in part, to a reproductive rate that is three-times lower than their known potential. This project was conducted to assess the impact of inbreeding on individual fitness within this species. Previously collected demographic and genetic data were used to calculate measures of both fitness and inbreeding for individual right whales. Fitness was measured through the use of the de-lifing method, and the inbreeding coefficient quantified was the internal relatedness calculation. Linear regression analyses showed that inbreeding explains little of the variation in both survival and fecundity for this species.

Yang et al. | URNCST Journal (2019): Volume 3, Issue 4

DOI Link: https://doi.org/10.26685/urnest.142 
UNDERGRADUATE RESEARCH IN NATURAL AND CLINICAL SCIENCE AND TECHNOLOGY (URNCST) JOURNAL Read more URNCST Journal articles and submit your own today at: https://www.urncst.com

\author{
Migratory stopover comparison of adult and juvenile semipalmated sandpipers (Calidris pusilla) in the Bay of Fundy \\ and on the Northumberland Strait \\ Siena S. Davis, BSc Student [1], Diana J. Hamilton, PhD [1], Julie Paquet [2] \\ [1] Department of Biology, Mount Allison University, Sackville, NB, Canada E4L 1G7 \\ [2] Canadian Wildlife Service, Environment and Climate Change Canada, 17 Waterfowl Lane, Sackville NB, E4L 1G6
}

Semipalmated sandpipers (Calidris pusilla) are a migratory shorebird that uses stopover sites in Atlantic Canada during their annual fall migration from the Arctic to South America. Studies of $C$. pusilla stopover ecology are important due to recent population declines and ecological changes. We examined two main questions: 1) Do adult and juvenile $C$. pusilla use different stopover strategies while in the region, and 2) How do C. pusilla use stopover sites in the Bay of Fundy (Johnson's Mills and Peck's Cove) versus on the Northumberland Strait (Petit-Cap)? We captured birds during August and September 2018 to collect blood samples for plasma triglyceride analysis (an index of fattening rate), collected prey samples, and observed foraging behaviour. There was no significant difference in fattening rates between adults and juveniles, or between sites. $C$. $p u$ silla spent a greater proportion of their time foraging and had higher pecking rates at Johnson's Mills compared to Petit-Cap. There were differences in availability of bivalves and gastropods between the Bay of Fundy and Northumberland Strait. Overall, my results suggest that while sites in the Bay of Fundy and Northumberland Strait have different characteristics, they are both valuable for $C$. pusilla to fatten and complete their fall migration.

Exploring gene expression during wound healing and limb regeneration in the common sea star, Asterias rubens: A research study

Alexandra M. Scovil, BSc Student [1], Russell H. Easy, PhD [1]

[1] Department of Biology, Acadia University, Wolfville, Nova Scotia, Canada B4P 2 R6

There are over 1500 species of sea stars living in aquatic ecosystems worldwide. The common sea star, Asterias rubens, is a marine invertebrate of the phylum Echinodermata, and is found predominantly in intertidal zones of the Northeast Atlantic Ocean. A. rubens have regenerative capabilities; they can undergo autotomy in response to a traumatic event and regenerate a genetically identical appendage. The objective of my research is to explore developmental genes involved in wound healing and arm regeneration in $A$. rubens. Using reverse transcription polymerase chain reaction, we explored four sets of genes involved in sea star regeneration including the immunoglobulin kappa region, genes for cysteine proteases, a homeobox domain, and an elongation factor subunit. Prior to experimental amputation, expression levels of all genes were not detectable. Following post-arm amputation, expression was seen in all genes of interest though the time at which this expression was detectable varied between gene targets. Since $70 \%$ of echinoderm genes have human homologs, understanding the regenerative capacity of sea stars may provide insight into the molecular basis of wound healing and regenerative capacities of higher vertebrates.

Pharmaceutical inhibition of FAK-mediated ion transport in killifish (Fundulus heteroclitus): A research study Breton C. Fougere, BSc Student [1], William S. Marshall, PhD [2]

[1] Department of Biology, St. Francis Xavier University, Antigonish, NS, Canada B2G 2W5

[2] Department of Biology, St. Francis Xavier University, Antigonish, NS, Canada B2G 2W5

Killifish tolerate drastic changes in environmental salinities using specialized gill epithelial cells, called ionocytes, which function to maintain homeostatic blood osmolality. These ionocytes are regulated by various signaling pathways, which modulate salt uptake or excretion. Focal adhesion kinase (FAK) is part of an integrin-mediated osmosensitive pathway that is an integral signaling protein in the ionocytes of killifish, but the pathway in which it is involved is still being investigated. Electrophysiology experiments were performed using Ussing chambers to examine the effects of a FAK inhibitor Y15 and the c-SRC inhibitor saracatinib on ion transport across the opercular epithelia. Epithelia were subjected to hypotonic shock to dephosphorylate FAK and reduce ion transport, then returned to isotonicity to examine FAK-mediated recovery. Epithelia treated with Y15 showed a significant decrease in short-circuit current recovery across the epithelia after returning to isotonicity. However, epithelia treated with saracatinib showed no significant effect on the short-circuit current during any treatment. Treatment with Y15 demonstrated an inhibitory effect on the recovery of ion transport after hypotonic shock. This inhibition of ion transport further supports previous hypotheses on the integral role FAK plays in the ion secretion in killifish and gives insight into the FAK signaling in teleost fish.

Yang et al. | URNCST Journal (2019): Volume 3, Issue 4

Page A5 of A22

DOI Link: https://doi.org/10.26685/urnest.142 
UNDERGRADUATE RESEARCH IN NATURAL AND CLINICAL SCIENCE AND TECHNOLOGY (URNCST) JOURNAL Read more URNCST Journal articles and submit your own today at: https://www.urncst.com

Development of a dermal protein scaffold for the treatment of full-thickness skin wounds

Evan D. D. Kotler, BSc Student [1], Elena Garcia-Gareta, PhD [2], William S. Marshall, PhD [3]

[1] Department of Biology, St. Francis Xavier University, Antigonish, Nova Scotia, Canada, B2G 2 W5

[2] Regenerative Biomaterials Group, Restoration of Appearance and Function Trust, Northwood, Middlesex, United Kingdom, HA6 $2 R N$

[3] Department of Biology, St. Francis Xavier University, Antigonish, Nova Scotia, Canada, B2G 2W5

The skin is the largest organ of the body by mass, and functions as a protective, thermoregulatory and sensory organ. The complexity of the dermal layer means that damage to this layer can result in permanent impairment of function. Dermal scaffolds are capable of promoting healing by providing structural support to promote cellular infiltration and vascular ingress. This study aimed to develop a dermal scaffold using collagen, fibrin and elastin proteins, and optimize the proportions of proteins present in the scaffold. A protein scaffold was constructed and investigated via material characterization, in vitro cellular analysis and an ex ovo vascular assay. Material characterization confirmed the presence of a gradient pore structure across all scaffolds, as well as varying degradation times correlated to the proportion of collagen within the scaffold. The scaffolds did not inhibit cellular infiltration, and all scaffolds were capable of promoting vascular ingress.

Novel application method for a seaweed extract biofertilizer: A research study Cameron G. Dalzell, BSc Student [1], Houman Fei, PhD [1], Joseph K. Vessey, PhD [1]

[1] Department of Biology, Saint Mary's University, Halifax, Nova Scotia, Canada B3H 3 C3

Applications of Ascophyllum nodosum extracts to crops can improve yield by modifying root morphology to increase nutrient uptake. For the standard liquid formulation of this biostimulant, frequent periodic applications are needed during the growing season. The expense of these repeated applications has led to investigations of slow-release formulations, which enhance the effects of fertilizers by prolonging their exposure time to roots. This presents the opportunity for an efficient and economic alternative to liquid formulations. The current experiment compared the growth effects of slow-release formulations of Ascophyllum nodosum extract on maize (Zea mays L.) to controls of water, liquid seaweed extract, and the slow-release formulation minus the seaweed extract. We predicted that the slow-release formulations of Ascophyllum nodosum extract would result in better growth than the liquid seaweed extract. Twelve slow-release formulations (comprised of four seaweed concentrations) were created from a composite of two organic compounds and Ascophyllum nodosumextract. Experiments were carried out in randomly distributed pots within a greenhouse. Maize height, leaf area, growth stage, biomass, and crop/soil nutrient content were collected after two months of growth. Preliminary results show the greatest growth response in maize from some of the slow-release formulations.

Evolution of conspecific brood parasitism in Red-breasted Mergansers: A research study Kristen M. Noel, BSc Student [1], Shawn R. Craik, PhD [1] [1] Department of Science, Université Sainte-Anne, Churchpoint, Nova Scotia, Canada, B0W 1M0

Introduction: Conspecific brood parasitism is a common reproductive tactic in waterfowl. It has been suggested that kinbiased brood parasitism (kin selection) can facilitate the evolution of conspecific brood parasitism in this group of birds. A recent model has shown that the accuracy of kin discrimination by the host is an important mechanism for kin selection. However, the amount of time that a host spends at her nest during egg-laying may limit the host's potential for discriminated kin and non-kin.

Methods: We parameterized the model using field data from a population of Red-breasted Mergansers (Mergus serrator), a duck species in which conspecific brood parasitism is common and incubation begins with the laying of the last egg.

Results: Our results show that, although costs of conspecific brood parasitism to host fitness are low enough to promote parasitism by kin, the possibility for hosts to detect brood parasitism during laying in this species is very low.

Conclusion: It thus seems unlikely that kin discrimination can facilitate the evolution of conspecific brood parasitism in this population of Red-breasted Mergansers.

Yang et al. | URNCST Journal (2019): Volume 3, Issue 4

Page A6 of A22

DOI Link: https://doi.org/10.26685/urnest.142 
UNDERGRADUATE RESEARCH IN NATURAL AND CLINICAL SCIENCE AND TECHNOLOGY (URNCST) JOURNAL Read more URNCST Journal articles and submit your own today at: https://www.urncst.com

Macrophage migration is affected by the stiffness but not porosity of the stromal collagenous matrix in vivo Evan. J Pugh, BSc Student [1], Bryan D. Crawford, PhD [1]

[1] Department of Biology, University of New Brunswick, Fredericton, NB, Canada E3B 5A3

Introduction: Cell migration is regulated by factors including the density, stiffness, and porosity of the extracellular matrix (ECM), activity of proteases, and the deformation of nuclei by matrix fibrils. Speed of cell migration should therefore be sensitive to experimental perturbation of proteases that degrade fibrillar collagens, collagen crosslinking, and nuclear volume. Methods: I collected 4-dimensional (x, y, z + time) movies of macrophages undergoing directional migration through regions of both dense and sparse ECM, in zebrafish embryos treated with inhibitors of Mmp13 and lysyl oxidase, and with normal (diploid) or larger (triploid) nuclei.

Results: Macrophages migrate faster in regions of sparse ECM. In regions of dense ECM, Mmp13 inhibition decreased the speed of macrophage migration, and collagen crosslinking increased the speed of migration. Increased nuclear size has no effect on the speed of macrophage migration.

Conclusion: Macrophages activate Mmp13 when migrating through dense, but not sparse ECM in-vivo. Blocking the actions of this protease slows cellular migration, as does reducing stiffness of the matrix by blocking crosslinking. Finally, as nuclear size does not affect migration, I conclude that matrix stiffness, and not porosity, limits macrophage migration.

Investigating the phycobiliprotein composition in the poorly studied glaucophytes Gloeochaete wittrockiana and Cyanoptyche gloeocystis

Clarissa C. Lalla, BSc Student [1]

[1]Department of Biology, University of New Brunswick, Fredericton, New Brunswick, Canada E3B 5A3

Glaucophytes are a rare group of algae essential for investigating the origin and evolution of photosynthetic eukaryotes. They possess several traits similar of their cyanobacterial ancestors, including light-harvesting complexes called phycobilisomes composed of diverse phycobiliproteins (pigmented proteins). It has been hypothesized that glaucophytes have a unique phycobiliprotein composition (c-phycocyanin and allophycocyanin) that could be useful in their detection. Of the four described glaucophyte genera, the phycobiliprotein composition has been investigated only in Cyanophora and Glaucocystis. I examined the phycobiliprotein composition in the poorly studied Cyanoptyche gloeocystis and Gleochaete wittrockiana as part of an integral project aiming to facilitate the identification of novel glaucophyte specimens in the environment. Using mechanical disruption and solubilization, I extracted photosynthetic pigments from Gleochaete wittrockiana and Cyanoptyche gloeocystis cell pellets. Then, using linear sucrose density gradients and ultracentrifugation; I separated, collected and analyzed pigmentcontaining fractions to identify the absorbance peaks expected for phycocyanin and allophycocyanin. I detected both c-phycocyanin and allophycocyanin in Gleochaete wittrockiana, while only c-phycocyanin was present in Cyanoptyche gloeocystis. No other phycobiliproteins were detected. My results suggest that all known glaucophyte genera have either c-phycocyanin or both c-phycocyanin and allophycocyanin, indicating that their presence is useful for the detection of glaucophytes in nature.

Determination of genome size, chromosome number and chromosomal ploidy in Aponogeton madagascariensis (lace plant): A research study

Cailyn M. Zamora, BSc Student [1]

[1] Department of Biology, Dalhousie University, Halifax, Nova Scotia, Canada, B3H 4R2

The lace plant is an aquatic monocot that is native to Madagascar. Lace plant leaves develop perforations through programmed cell death (PCD) making it an outstanding potential model organism. Little to no genetic information is known about the lace plant or members of the Aponogetonaceae family. The importance of the lace plant as a model requires the establishment of genetic information. Therefore, this study aims to determine genome size, chromosome number and ploidy level. Genome size was analyzed using flow cytometry. To obtain chromosome counts, healthy root tips or anthers were treated in a solution of 8hydroxyquinoline to halt active cell division at metaphase. Roots were crushed into a fine powder using liquid nitrogen or digested with cellulase and pectinase to isolate root protoplasts. The powder or protoplast solution was stained with DAPI and observed using confocal microscopy. Micrographs and z-stacks of stained chromosomes were counted using ImageJ image processing software. Preliminary counts from the root squash support a chromosome number of 80 which will be verified through more replicates. Flow cytometry revealed a genome size of $1.01 \mathrm{pg} / \mathrm{C}(\sim 995 \mathrm{Mbp} / \mathrm{C})$ with more experimental replicates currently being tested. We will attempt to determine the ploidy level by performing Fluorescent In Situ Hybridization

Yang et al. | URNCST Journal (2019): Volume 3, Issue 4

DOI Link: https://doi.org/10.26685/urnest.142 
UNDERGRADUATE RESEARCH IN NATURAL AND CLINICAL SCIENCE AND TECHNOLOGY (URNCST) JOURNAL Read more URNCST Journal articles and submit your own today at: https://www.urncst.com

\section{Oral Presentations in Aquaculture \& Fisheries}

Loop-mediated isothermal amplification (LAMP) as a tool for rapid detection of Saprolegnia parasitica in salmonid farms: A research study

Emily C. Kraemer, BSc Student [1], Mohammad N. Sarowar, PhD [2]

[1] Department of Biology, Dalhousie University, Halifax, NS, Canada B3H 4R2

[2] Department of Animal Science and Aquaculture, Dalhousie University, Truro, NS, Canada B2N 5E3

One of the challenges of salmonid aquaculture is the management of devastating fungal disease outbreaks caused by the freshwater pathogen Saprolegnia parasitica. The existing technique to diagnose the disease involves PCR and sequencing of the internal transcribed spacer (ITS) region of rDNA of fungal mycelia from infected fish, which can be time consuming and expensive. To develop an environmental DNA detection technique that is simpler, faster and much more specific, Loop-Mediated Isothermal Amplification (LAMP) may be a useful tool. Unlike conventional PCR, six different primers were designed using PrimerExplorer V5 from the ITS region of Saprolegnia parasitica. DNA from a number of Saprolegnia spp. was also tested to evaluate specificity of the primers. Successful amplification was run at a constant $71^{\circ} \mathrm{C}$. Amplification was detected by turbidity change and visualization by gel electrophoresis. The designed primers were able to specifically probe different $\mathrm{S}$. parasitica strains and resulted in turbid end products in 30 minutes. The LAMP eDNA detection method is straightforward and rapid for detection of Saprolegnia parasitica in salmonid farms sites and may prove to be a useful tool for the diagnostics of the disease.

The effect of ploidy and acclimation temperature on temperature and hypoxia tolerance in brook charr (Salvelinus fontinalis)

Rebecca R. Porter, BSc Student [1], Tillmann J. Benfey, PhD [1]

Department of Biology, University of New Brunswick, Fredericton, NB, Canada, E3B 5A3

Atlantic salmon are farmed globally due to the wild population being too low to support a fishery. However, farmed salmon have the potential to escape and mate with the remaining wild stock of fish, impacting the genetic makeup of the wild population. Induced triploidy is an effective way to make salmon effectively sterile to reduce genetic impacts on wild populations. Previous studies have shown a tendency of triploids to underperform under conditions of hypoxia and high temperature, however the results are mixed. The goal of this study was to determine if triploid salmonid fish differ from diploids in tolerance to high temperature and hypoxia, as well as to determine the physiological cause for loss of equilibrium under such conditions. This study used diploid and triploid brook charr (Salvelinus fontinalis) acclimated to three temperatures $\left(12^{\circ} \mathrm{C}, 15^{\circ} \mathrm{C}\right.$ and $\left.18^{\circ} \mathrm{C}\right)$ in a series of hypoxia challenges at $10^{\circ} \mathrm{C}$ above the acclimation temperature, at two different rates of oxygen depletion $(0.5 \% /$ minute and $0.75 \% /$ minute $)$. Neither ploidy nor rate of oxygen depletion effected the oxygen tension at loss of equilibrium in these experiments. However, the fish acclimated to $18^{\circ} \mathrm{C}$ were significantly more susceptible to hypoxia than those acclimated to lower temperatures. Condition factor was found to be significant in predicting oxygen tension at loss of equilibrium. Blood hemoglobin concentration was not found to predict hypoxia tolerance. The lack of difference between diploid and triploid fish indicates that the physiological response to temperature and hypoxia stress may be the same for both ploidies.

Acanthocephala infestations in striped bass Morone saxatilis from two populations of Shubenacadie River and Miramichi River

Shangning Wang, BSc Student [1], Jim, Duston, PhD [2]

[1] Department of Animal Science and Aquaculture, Dalhousie University, Truro, Nova Scotia, B2N 5 E3.

Striped bass from the Shubenacadie River stock were heavily infected with thorny-headed worms (Acanthocephala) in the lower intestine, whereas the parasite was absent among $\mathrm{n}=16$ adults from the Miramichi River. DNA analysis of the $18 \mathrm{~S}$ nuclear ribosomal region identified the worm as Pomphorhynchus sp., the first report of this species in the Maritimes. The incidence of infection among Shubenacadie River stock was 94\% (49 out of 52). Mean (SE) infestation rate per fish was positively related to the body weight (BW): 35 (5.3) among fish <1 kg, 100 (23.3) among fish 1-3 kg, and 839 (106.0) among adults ranging from $4-10 \mathrm{~kg}$. The parasite appeared to cause no harm to the fish, both stocks appeared equally healthy. Shubenacadie bass exhibited no external gross abnormalities, and infestation rate was independent of both condition factor $\left(\mathrm{CF}=\mathrm{BW} / \mathrm{Fork}\right.$ length $\left.{ }^{3 *} 100\right)$ and fecundity among mature females. The reason for the absence of this helminth parasite from the Miramichi striped bass is unknown; the lack of a suitable intermediate invertebrate host is one possibility.

Yang et al. | URNCST Journal (2019): Volume 3, Issue 4

Page A8 of A22

DOI Link: https://doi.org/10.26685/urnest.142 
UNDERGRADUATE RESEARCH IN NATURAL AND CLINICAL SCIENCE AND TECHNOLOGY (URNCST) JOURNAL Read more URNCST Journal articles and submit your own today at: https://www.urncst.com

Eyespots or no eyespots: Seeing is not believing where morphological differences in cryptic species of skates is concerned Gwendolyn M. Ough, BSc Student [1] Trevor Avery, PhD, PStat [2]

[1] Department of Biology, Acadia University, Wolfville, NS, Canada B4P 2R6

[2] Biology and Mathematics \& Statistics Departments Acadia University, Wolfville, NS, Canada B4P 2R5

Two species of skates residing in the Minas Basin and Bay of Fundy, Little Skate, Leucoraja erinacea, and Winter Skate, Leucoraja ocellata, share many morphological similarities making them difficult to distinguish. This crypticism can cause fisheries bycatch records to be unreliable and the relative populations could be affected differentially if the species are managed or conserved as a complex. Many identification guides state Winter Skate grow larger and have eyespots whereas Little Skate are smaller and without eyespots. The study objective was to investigate differences between species commonly used to distinguish them but suggested by past research not to be reliable. Over 11,000 skates were caught in Avon Estuary, Scots Bay, or Bay of Fundy/Scotian Shelf, Nova Scotia, and about 1,000 were identified to species using genetics. A subset was measured for total length, weighed, and eyespots identified (presence/absence) and/or counted. The relationship of body size, eyespots, and capture location was modeled. We found the presence of eyespots in both species to be variable and no significant relationship existed between size and eyespots or number of eyespots. Some collection region differences were shown, but only when pooling species (thus increasing sample size) suggesting eyespots may be environmentally driven. However, there was potential unintentional bias in skates selected for species identification which may preclude regional results. Preliminary analyses are provided.

Effects of hypoxia, normoxia, and hyperoxia on sex determination in zebrafish (Danio rerio) when observing diploid and triploid populations: A research study Emily R. Moore, BSc Student [1], Tillmann J. Benfey, PhD [2]

[1] Department of Biology, University of New Brunswick, Fredericton, New Brunswick, Canada E3B 5A3

[2] Department of Biology, University of New Brunswick, Fredericton, New Brunswick, Canada E3B 5A3

Introduction: Danio rerio is a model species that is widely used in the biomedical research field. Most captive populations have skewed sex ratios. Populations are known to be affected by differing levels of dissolved oxygen. Hypoxia is affecting thousands of cubic kilometers of water, and has caused declines in many fish populations. Furthermore, it has been reported that populations of triploid Danio rerio are all male. This study aims to test the effects of low, normal, and high dissolved oxygen levels on the development and sex ratio of diploid and triploid populations.

Methods: Experimental populations were made using in-vitro fertilization followed by pressure shock to induce triploidy in half of the eggs. At 24 hours post fertilization (hpf), embryos were exposed to either low (50\%), normal (100\%), or high (150\%) dissolved oxygen levels for 4 hours. They were then reared in Petri-dishes until $144 \mathrm{hpf}$, after which they were then moved into flow-through tanks where they will be raised until adulthood. Sex ratio will then be determined by sexing fish in each population based on their general appearance (body depth and colour) and the presence/ absence of male-specific spawning tubercles on the pectoral fins.

Results: It is predicted that the hypoxic diploid population will be mostly male, that the normoxic diploid population will be $\sim 50 \%$ male, and that the hyperoxic diploid population will be mostly female. It is also predicted that all the triploid populations will be male.

Conclusion: Study to be completed by May 2019.

Estimating abundance of brook trout (Salvelinus fontinalis) populations using parent-offspring relationships Daniela V. Notte, BSc Student [1], Daniel E. Ruzzante, PhD [1]

[1] Department of Biology, Dalhousie University, Halifax, NS, Canada B3H 4R2

Estimating population abundance is a central goal in conservation biology and fisheries management. Traditionally assessed through catch-per-unit-effort trends, abundance estimates are often difficult to ascertain especially for widespread and inaccessible marine populations. The close-kin mark-recapture (CKMR) method of estimating population abundance employs genetic data to identify parent-offspring pairs (POPs) and analyzes them in a modified mark-recapture framework. An individual marks its parents by sharing genetic information and is recaptured by its parent's genotype. My objective was to test the feasibility of CKMR for estimating abundance of wild fish populations. I sampled 7 freshwater resident brook trout (Salvelinus fontinalis) populations in the North Mountain, Nova Scotia via double-pass electrofishing in the summers of 2014 to 2018. Individuals were genotyped at 31 microsatellite loci to determine the number of POPs. After applying information on age-specific fecundity

Yang et al. | URNCST Journal (2019): Volume 3, Issue 4

DOI Link: https://doi.org/10.26685/urnest.142 
UNDERGRADUATE RESEARCH IN NATURAL AND CLINICAL SCIENCE AND TECHNOLOGY (URNCST) JOURNAL Read more URNCST Journal articles and submit your own today at: https://www.urncst.com

and survival, this number was then used to calculate population size. CKMR estimates were compared to standard mark-recapture estimates. CKMR provided accurate abundance estimates for 4 populations, 2 populations were projected to be much smaller than mark-recapture values, and no POPs were identified for 1 population. CKMR is a promising method for estimating population abundance and with further refinement may be used in fisheries management.

Determining the effects of dietary eicosapentaenoic acid (EPA) and docosahexaenoic acid (DHA) level on health and growth of Atlantic salmon (Salmo salar)

Cheng Qian, BSc Student [1], Stefanie M. Colombo, PhD [1]

[1] Department of Animal Science and Aquaculture, Dalhousie University, Truro, Nova Scotia, B2N 5E3.

The effects of low dietary EPA and DHA levels on growth performance of Atlantic salmon (Salmo salar) were determined in this study. Salmon (initial weight $22.6 \mathrm{~g} \pm 1.2)$ were fed four levels $(0.25,0.5,0.75$ and $2 \%)$ of EPA + DHA diets for 6 weeks in freshwater at $12{ }^{\circ} \mathrm{C}$. Diets were fed to triplicate tanks, with 15 fish per tank. All fish appeared healthy and there were no mortalities throughout the trial. The $0.25 \%$ EPA + DHA group showed significantly different growth performance than other three groups, including higher feed conversion rate (FCR) at 0.86 and lower specific growth rate (SGR) at $1.27 \% /$ day. The remaining treatments above $0.5 \% \mathrm{EPA}+\mathrm{DHA}$ showed FCR below 0.75 and SGR above $1.42 \% /$ day. In addition, the condition factor of control group was higher (1.14) than the other treatments (from 1.20 to 1.22). Based on growth performance alone, $0.5 \% \mathrm{EPA}+\mathrm{DHA}$ appears to be sufficient to maintain overall health and growth. But once reducing dietary EPA + DHA to $0.25 \%$, there is a significantly negative impact on fish growth.

The effect of diel thermal cycles on metabolism and performance in wild Atlantic salmon (Salmo salar) Sula Swart, BSc Student [1], Jenna Morissette, BSc Student [1], Tyson MacCormack, PhD [2], Andrea Morash, PhD [1], Suzie Currie, PhD [3]

[1] Department of Biology, Mount Allison University, Sackville, NB, E4L 1E2

[2] Department of Chemistry \& Biochemistry, Mount Allison University, Sackville, NB, E4L 1E2

[3] Department of Biology, Acadia University, Wolfville, NS, B4P 2R6

Understanding the effects of rising temperatures on the physiology of fish is crucial to predict their future survival. Lab experiments to investigate the thermal physiology of fish are typically performed at constant temperatures, not representative of their natural thermal habitat that varies daily. Evidence suggests that the physiological responses to thermal variability may be different than responses to thermally stable environments. However, we know little about the effects of natural temperature variability on performance and fitness in Atlantic salmon. To this end, we investigated the effects of a thermal cycle, with and without a thermal challenge, on aerobic and anaerobic metabolism and swim performance. Salmon were acclimated to a cycle of $16-21^{\circ} \mathrm{C}$ or stable temperatures of $16^{\circ} \mathrm{C}, 18.5^{\circ} \mathrm{C}$ (cycle average), and $21^{\circ} \mathrm{C}$ (experiment 1 ; no thermal challenge), and 16 $21^{\circ} \mathrm{C}$ or $19-24^{\circ} \mathrm{C}$ (experiment 2 ; thermal challenge). We found no significant effect of thermal cycling on metabolism or aerobic swim performance. Furthermore, preliminary results indicate that thermal cycling, with a thermal challenge, does not appear to affect anaerobic performance. These data will help to gain a better understanding of how Atlantic salmon cope with predicted, real-world patterns of temperature increases/variability associated with climate change.

Selective forces on alternative reproductive strategies of Atlantic salmon (Salmo salar) in the Os and Flåm Rivers in Norway

Heather Perry, BSc Student [1] Jeffrey Hutchings [2]

[1] Department of Biology, Dalhousie University, Halifax, Nova Scotia, Canada B3H 4 R2

Male Atlantic salmon (Salmo salar) exhibit one of two alternative mating strategies. Some mature as parr in their natal rivers, while others mature as 'anadromous males' following a marine migration. Collectively, mature male parr fertilize a substantial portion of eggs by sneaking into redds during spawning. Although mature parr are more likely to survive until reproduction, their average fertilization success is considerably lower than that of anadromous males. Such life-history trade-offs influence their size, gonadal investments and reproductive schedule. Despite extensive studies of alternative reproductive strategies in Atlantic salmon, remarkably little temporal information is available for wild populations. This study explores annual electrofishing data collected by Norwegian researchers on parr from the Os and Flåm rivers between 1996 and 2016 . Statistical analyses of age, sex, maturity, length, weight and gonadosomatic index were used to elucidate how selective forces act on each strategy. The research had three focuses; the importance of juvenile size in determining male reproductive strategy, effects of

Yang et al. | URNCST Journal (2019): Volume 3, Issue 4

DOI Link: https://doi.org/10.26685/urncst.142 
UNDERGRADUATE RESEARCH IN NATURAL AND CLINICAL SCIENCE AND TECHNOLOGY (URNCST) JOURNAL Read more URNCST Journal articles and submit your own today at: https://www.urncst.com

mature parr density on their gonadosomatic index, and timing of marine migration. The study contributes to our central understanding of how alternative reproductive strategies are established and maintained in Atlantic salmon populations which may have implications for their sustainable management.

Exploring cryopreservation of shortnose sturgeon sperm: A research study Samantha A. Feener, BSc Student [1], Matthew K. Litvak, PhD [1]

[1] Department of Biochemistry, Mount Allison University, Sackville NB, Canada, E4L 1H3

Shortnose sturgeon (Acipenser brevirostrum) are distributed along the eastern coast of North America. They are listed as endangered in the US and as a species of special concern in Canada. Development of methods for conservation, such as development of sperm cryobanks, is imperative for their protection. Cryopreservation protocols must prevent cellular damage from ice crystal formation in spermatozoa and permit normal activity after reanimation. This involves development of cryoprotectants, determination of equilibration time for cryoprotectants, as well as freezing and thawing rates. Current methods to cryopreserve shortnose sturgeon sperm result in low post-thaw sperm motilities. The current approach uses "Modified Tsvetkova's extender" as a cryoprotectant. We modified the standard protocol by using methanol and altering potassium chloride concentration. We examined the effect of these factors on sperm motility and curvilinear velocity. Additionally, we determined cellular damage through quantification of lactate dehydrogenase levels in seminal plasma, pre- and post-freeze. Preliminary results from our study indicate that longer equilibration time resulted in higher post-thaw motility and less cell damage during the cryopreservation process. Our work provides a platform for further development of sperm cryopreservation protocols for this endangered species.

Determining the optimal embryonic stage to perform yolk swapping in zebrafish (Danio rerio) Emily J. Burbidge, BSc Student [1], Mathew K. Litvak, PhD [1]

[1] Department of Biology, Mount Allison University, Sackville, NB, Canada E4L 1E2

Zebrafish (Danio rerio) is a small cyprinid fish that has become one of the most important vertebrate models in the study of human health, genetics, developmental biology and evolutionary ecology. A large component of the zebrafish embryo is comprised of the yolk sac, which is filled with maternally derived nutrients. The objectives of our study were to determine if we could successfully swap zebrafish yolk with chicken yolk (Gallus gallus) and to identify the optimal embryonic stage to swap yolk through microinjection/micromanipulation. We swapped $22 \mathrm{~nL}$ of zebrafish yolk with chicken yolk at four different developmental stages: cleavage, blastulation, gastrulation, and early segmentation. Sham and control treatments were also performed at each stage. Following manipulation, larval survival and body morphology was monitored daily until starvation using image analysis. Preliminary results of our study show that yolk swapping with chicken yolk can produce viable zebrafish larvae and that manipulation during early segmentation provides increased survivorship. These findings suggest: 1) the conserved nature of yolk across taxa; 2) importance of timing in yolk-sac microinjection/micromanipulation; and 3) that yolk-swapping may provide an opportunity to generate a rapid and cost-effective approach to study broodstock diet formulations.

Exploring gene expression during wound healing and limb regeneration in the common sea star, Asterias rubens: A research study

Alexandra M. Scovil, BSc Student [1], Russell H. Easy, PhD [1]

[1] Department of Biology, Acadia University, Wolfville, Nova Scotia, Canada B4P 2 R6

There are over 1500 species of sea stars living in aquatic ecosystems worldwide. The common sea star, Asterias rubens, is a marine invertebrate of the phylum Echinodermata, and is found predominantly in intertidal zones of the Northeast Atlantic Ocean. A. rubens have regenerative capabilities; they can undergo autotomy in response to a traumatic event and regenerate a genetically identical appendage. The objective of my research is to explore developmental genes involved in wound healing and arm regeneration in A. rubens. Using reverse transcription polymerase chain reaction, we explored four sets of genes involved in sea star regeneration including the immunoglobulin kappa region, genes for cysteine proteases, a homeobox domain, and an elongation factor subunit. Prior to experimental amputation, expression levels of all genes were not detectable. Following post-arm amputation, expression was seen in all genes of interest though the time at which this expression was detectable varied between gene targets. Since $70 \%$ of echinoderm genes have human homologs, understanding the regenerative capacity of sea stars may provide insight into the molecular basis of wound healing and regenerative capacities of higher vertebrates.

Yang et al. | URNCST Journal (2019): Volume 3, Issue 4

DOI Link: https://doi.org/10.26685/urnest.142 
UNDERGRADUATE RESEARCH IN NATURAL AND CLINICAL SCIENCE AND TECHNOLOGY (URNCST) JOURNAL Read more URNCST Journal articles and submit your own today at: https://www.urncst.com

\author{
Seasonal distribution and network analysis of shortnose sturgeon (Acipenser brevirostrum) in the lower Saint John River \\ basin \\ Brent A. Walker, BSc Student [1], Mathew K. Litvak, PhD [1] \\ [1] Department of Biology, Mount Allison University, Sackville, NB, Canada E4L 1E2
}

Shortnose sturgeon (Acipenser brevirostrum) are a species of special concern in Canada. The Saint John River population is their only known occurrence in the country. We used acoustic telemetry to assess the seasonal distribution and coarse-scale movement of shortnose sturgeon in the lower Saint John River basin. Fifty-six individuals were tagged and passively monitored using 25 acoustic telemetry receivers distributed throughout the river. We used a series of movement and residence indices to compare the relative importance of specific river reaches between seasons. Distribution and movement networks varied by season. Individuals visited up to $72 \%$ of all stations and exhibited higher residency within the array from September-November. Over $79 \%$ of winter detections $(n=61,099)$ occurred near river kilometer 105, suggesting a previously unknown overwintering site. Coarse-scale network analysis is critical for identifying important habitat and making informed management decisions regarding the conservation of shortnose sturgeon throughout their natural distributions

\author{
Movement patterns of American eel, Anguilla rostrata, using PIT Tags in the Avon Estuary \\ Madeleine S. Killacky, BScH Student, BAH, MA Student [1], Trevor Avery, PhD, PStat [2] \\ [1] Departments of Biology and English Literature, Acadia University, Wolfville, Nova Scotia, Canada, B4P 2 R6 \\ [2] Departments of Biology and Mathematics \& Statistics, Acadia University, Wolfville, Nova Scotia, Canada, B4P 2R6
}

American Eels, Anguilla rostrata, are a catadromous species that live in freshwater as adults but embark on a famously secretive journey into salt water to spawn in the Sargasso Sea. Because these eels utilize both fresh and saltwater systems to complete their life cycle, the growing number of tidal barriers being built along the coast has potential to impede their natural movement and migration patterns. The Avon Estuary, Windsor, Nova Scotia, is currently an important site for research because plans are in progress to install a new flood control gate-way as the highway is twinned. Fish passage is a requirement. Previous studies have found American Eel, Anguilla rostrata, are present in two locations adjacent to the Windsor causeway: in the tidal waters proximal and distal to the gate, and in the brackish and fresh waters up-river from this location. The objective of this study was to investigate movement patterns of American Eel between the fresh and tidal waters, other than during their annual spawning migration, using Passive Integrated Transponder (PIT) tags. This research is important because it will help inform decisions on gate-way design and potential impacts to local American Eel movement and migration patterns. Eels were caught between 11 April - 6 November 2018. 57 different eels were recaptured at least once with 100 recaptures in total. Of recaptured eels, most often they were recaptured only once. Results indicated that there was no movement of tagged eels between the two test sites suggesting that the current fish-gate system is inadequate for free fish movement.

\title{
$\underline{\text { Poster Presentations in Biology }}$
}

Extent of plasticity in the nuptial body coloration of the white ecotype of the Threespine Stickleback (Gasterosteus aculeatus)

Rachel H. Corney, BSc Student [1], Laura K. Weir, PhD [2]

[1] Department of Biology, Saint Mary's University, Halifax, Nova Scotia, Canada B3H C3C

[2] Department of Biology, Saint Mary's University, Halifax, Nova Scotia, Canada B3H C3C

Animals may use a suite of behavioural and morphological traits to compete for mates. Some species may exhibit nuptial colouration, a signal that functions in female choice, and/or male competition. During breeding, male Threespine Sticklebacks build and defend a nest from competitors and court females. They also turn a shade of red and blue to help amplify these behaviours. Male white Threespine Stickleback, an ecotype endemic to Nova Scotia, also display nuptial colouration. However, whether this colouration functions in female choice or male competition is poorly understood. The goal of this study was to determine the association between the breeding phase and nuptial colouration of the white ecotype. Males were exposed to conditions that mimicked their main breeding phases: nest-building, territory defense, and mate acquisition. The nest-building condition acted as a baseline to quantify the males' colouration before being exposed to a competitor or a female. Male colouration was quantified to determine the influence of the conditions. Male colouration was significantly different for nest-building compared to the other phases. However, there was no significant difference between the male competition and female choice phase. This suggests that the white ecotype's nuptial colouration may be associated with male competition and female choice.

Yang et al. | URNCST Journal (2019): Volume 3, Issue 4

DOI Link: https://doi.org/10.26685/urnest.142 
UNDERGRADUATE RESEARCH IN NATURAL AND CLINICAL SCIENCE AND TECHNOLOGY (URNCST) JOURNAL Read more URNCST Journal articles and submit your own today at: https://www.urncst.com

The effects of water temperature on the resting and post-exercise physiology in juvenile Atlantic sturgeon (Acipenser oxyrinchus) Ryan N. Miller, BSc Student [1], James D. Kieffer, PhD [1]

[1] Department of Biological Sciences, University of New Brunswick, Saint John, New Brunswick, Canada E2E 1R5

The effects of water temperature on the resting and post-exercise physiology were investigated in juvenile Atlantic sturgeon (Acipenser oxyrinchus). The response of various hematological parameters (e.g. protein and lactate) were measured at varying temperatures after four weeks of acclimation, at rest (at $3{ }^{\circ} \mathrm{C}, 6^{\circ} \mathrm{C}$, or $9{ }^{\circ} \mathrm{C}$ ), or following five minutes of exhaustive exercise (at $3{ }^{\circ} \mathrm{C}$ or $9{ }^{\circ} \mathrm{C}$ ). At the lowest temperatures, fish appeared motionless and generally were positioned at the bottom of the tank. At the warmer temperatures, fish were visibly more active. Resting glucose, protein, lactate, and hematocrit levels were similar across temperatures, and resting osmolality values were lowest at $9^{\circ} \mathrm{C}$. Post-exercise lactate, glucose and hematocrit levels were similar at 3 and $9{ }^{\circ} \mathrm{C}$. Post-exercise osmolality values increased at $9^{\circ} \mathrm{C}$ only, and levels of protein decreased at both temperatures. Overall, the data suggest that sturgeon can survive at the lowest temperatures, but it appears that sturgeon don't respond to the manual chasing protocol and don't show the typical physiological response to this type of exercise (i.e., increased glucose, lactate and osmolality). A small pilot project was conducted to determine if juvenile fish would swim in a swimming respirometer. Of the fish tested, none were able to swim, perhaps suggesting that juvenile sturgeon swimming capacity is constrained by colder temperatures. To support this hypothesis, juvenile sturgeon may conserve their energy by station holding and remaining motionless at colder temperatures.

Waiting for what? Explaining variation in the timing of female reproduction

Ting Yat M. Lee, BSc Student [1], Shelley A. Adamo, PhD [2]

[1] Department of Biology, Dalhousie University, Halifax, NS, B3H 4R2

[2] Department of Psychology and Neuroscience, Dalhousie University, Halifax, NS, B3H 4R2

Natural selection favors individuals that maximize fitness, therefore fitness-related traits should have minimal variation. However, female crickets (Gryllus texensis) vary in reproductive timing; some start laying eggs (oviposition) early in adulthood (early layers), but others oviposit closer to the end of their life (late layers). Eggs are valuable, and hatching success depends on the oviposition substrate. I hypothesized that the late layers employ a strategy in which they postpone oviposition when the substrate is suboptimal. Instead of risking the loss of eggs due to poor conditions, they store their eggs in their ovaries until they are nearing the end of their life. To test this hypothesis, I categorized individuals into early and late layers and assigned them to having either suboptimal (cotton) or preferred (sand) substrate. I then monitored oviposition. I predicted that only the late layers would increase reproductive output when given sand and they would oviposit earlier. I found that both early and late layers laid more of their produced eggs in sand. However, late layers did not change their reproductive output when given sand. I am now testing whether other factors, such as flight (dispersal) and mate quality, will induce late layers to alter their reproductive output.

Site-specific incorporation of fluorescent ncAA ANAP in KSHV small capsid protein ORF65

Danika Knight, BSc Student [1], Brett Duguay, PhD [1,2], Craig McCormick, PhD [1,2,3]

[1] Department of Microbiology and Immunology, Dalhousie University, Halifax, NS, Canada B3H 4 H7

[2] Beatrice Hunter Cancer Research Institute, Halifax, NS, Canada B3H 4R2

[3] Canadian Center for Vaccinology, IWK Health Centre, Halifax, NS, Canada B3K 6R8

Human herpesvirus 8 (HHV8), more commonly known as Kaposi's sarcoma-associated

herpesvirus (KSHV), is the infectious cause of several human cancers. Many aspects of KSHV infection and cancer initiation remain obscure due to limitations in tools available for KSHV research. Recently, a system has been developed for incorporation of noncanonical amino acids (ncAA) during protein synthesis. This system requires a codon dedicated to ncAA incorporation, the ncAA-specific orthogonal aminoacyl-tRNA synthase (aaRS)/tRNA pair, and the specific ncAA to be incorporated. The fluorescent ncAA 3-(6-acetylnaphthalen-2-ylamino)-2-aminopropanoic acid (ANAP) expression system suppresses the amber stop codon, TAG, by incorporating ANAP in its place. This discrete system allows for protein study with minimal alterations to the native protein. Here, we report the incorporation of ncAAs into KSHV ORF65, a small capsid protein essential for capsid assembly which we mutated to introduce an amber stop codon in the middle of the open reading frame. We predict that ANAP incorporation will give rise to full-length ORF65 which can be determined through immunofluorescence and immunoblotting; in the absence of ANAP, nascent ORF65 polypeptides will be prematurely terminated. We predict that this strategy for ncAA incorporation into KSHV capsid proteins, if successful, will accelerate studies of viral assembly and egress.

Yang et al. | URNCST Journal (2019): Volume 3, Issue 4

DOI Link: https://doi.org/10.26685/urnest.142

Page A13 of A22 
UNDERGRADUATE RESEARCH IN NATURAL AND CLINICAL SCIENCE AND TECHNOLOGY (URNCST) JOURNAL Read more URNCST Journal articles and submit your own today at: https://www.urncst.com

\author{
Acoustic monitoring of Leach's storm-petrels (Oceanodrama leucohora) as an index of nesting density \\ Alison J. Gladwell, BSc Student [1], Robert R. Ronconi, PhD [1,2], Andrew G. Horn, PhD [1] \\ [1] Biology Department, Dalhousie University, Halifax, Nova Scotia, Canada, B3K 4R2 \\ [2] Canadian Wildlife Services, Dartmouth, Nova Scotia, Canada
}

Introduction: Population monitoring of burrowing, nocturnal seabirds is challenging, as species spend limited time on remote oceanic islands to breed. To attempt to mitigate this challenge, acoustic monitoring has been used to assess diurnal activity patterns in seabird populations, but rarely to assess whether acoustic recordings can be used to relate the call activity to the nesting density or population size.

Methods: From June-July, 2018, we distributed passive acoustic recorders across 21 sites throughout a colony of Leach's Storm-petrels (Oceanodrama leucohora) on Kent Island, New Brunswick. Recording sites varied in habitat types, nesting densities and exposure to predators. The nesting density was measured within the $7853.98 \mathrm{~m}^{\wedge} 2$ area centred on each acoustic meter. Recordings were analyzed using Raven acoustic software to estimate the average calls/hour of petrels and Herring Gulls (Larus argentatus), the petrels' main predator.

Results: Preliminary results suggest that call activity has the strongest relationship to local nesting density 8 hours after sunset $\left(\mathrm{R}^{\wedge} 2=0.47, \mathrm{p}=0.00029\right)$. Call rates indicate the first calls occur $\sim 2$ hours after sunset, and the last calls occurring $\sim 1$ hour before sunrise, typically peaking 5-7 hours after sunset. As the analysis continues, a general linear mixed model will be applied to assess if various environmental and phenological factors affect the relationship between call activity and nesting density.

Conclusion: Exploratory results may identify conditions that effect the diurnal patterns of storm-petrels, such as wind patterns and light exposure. Call activity can be used to estimate nesting density, so acoustic monitoring may be an effective tool for assessing populations of Leach's Storm-petrels on remote breeding islands.

Vegetation type affects nutrient concentrations in green roof runoff

Bridget E. Biermann, BSc Student [1], Jeremy T. Lundholm, PhD [2]

[1] Department of Biology, Saint Mary's University, Halifax, Nova Scotia, Canada B3H 3 C3

[2] Department of Biology/Environmental studies, Saint Mary's University, Halifax, Nova Scotia, Canada B3H 3 C3

Green (vegetated) roofs have been shown to provide a wide range of environmental benefits in urban areas. However, runoff from green roofs may contain soil nutrients like nitrogen and phosphorus, which are considered as contaminants when present in water. These contaminants degrade water quality, and as a result can lead to nutrient enrichment problems downstream. This study compares nutrient concentrations in the runoff from a modular, extensive green roof system among different vegetation types. Plant species differ in their nutrient requirements so identifying species with high nutrient demands could help reduce nutrient concentrations in runoff. Nutrient analysis of runoff was done both prior to, and following the addition of a slowrelease fertilizer. Preliminary results from runoff nutrient analysis show that, for both total nitrogen and nitrate nitrogen, vegetation had a strong effect. Treatments with overall higher amounts of living biomass, such as species mixtures and monocultures of Sedum acre, resulted in better runoff quality (i.e. lower nitrogen concentrations) than those with little to no biomass. The results suggest that nutrient uptake is driven by biomass production in green roof systems and that selection of higher biomass species or species mixtures can help improve the environmental performance of green roofs.

\title{
Treatment of Nosema adaliae-infected lady beetle Adalia bipunctata with antimicrobial manuka honey Kenja O. James, BSc Student [1], Susan Bjornson, PhD [1] [1] Department of Biology, Saint Mary’s University, Halifax, NS, Canada B3H 3 C3
}

The potential of biological control agents, such as the two-spotted lady beetle, Adalia bipunctata, against insect pests is greatly dependant on their ability to successfully mature to adulthood. However, intracellular parasites such as microsporidia, affects beetle growth and prolongs larval development. The aim of this research is to determine whether the effects of the pathogen, Nosema adaliae, are mitigated when its host, A. bipunctata, is reared on an antimicrobial diet of manuka honey. We compared development and mortality of infected lady beetles between four different treatment groups: the control was provided aphids and water, whereas the three treatment groups were given aphids and three different dilutions of honey (5\%, 10\% and $15 \%$ ), depending on treatment. Larval development for the control was $15.9 \pm 0.7 \mathrm{SE}$ days, whereas larval development for the treatment groups was $13.8 \pm 0.6,13.8 \pm 1.0$, and $13.3 \pm 0.9$ days for larvae that were provided with $5 \%, 10 \%$ and $15 \%$ manuka honey, respectively. While larval development decreased significantly with greater concentration of honey, larval mortality increased. The extent which each group was affected by the microsporidium could be indicative of the degree of infection and could account for the differences in development time and mortality.

Yang et al. | URNCST Journal (2019): Volume 3, Issue 4

DOI Link: https://doi.org/10.26685/urnest.142 
UNDERGRADUATE RESEARCH IN NATURAL AND CLINICAL SCIENCE AND TECHNOLOGY (URNCST) JOURNAL Read more URNCST Journal articles and submit your own today at: https://www.urncst.com

Gene expression profiles of potential selective estrogen receptor modulators in banded killifish (Fundulus diaphanus) Zachary B. Visser, BScH Chemistry [1], Russell H. Easy, PhD [2]

[1] Department of Chemistry, Acadia University, Wolfville, Nova Scotia, Canada, B4P 2R6

[2] Department of Biology, Acadia University, Wolfville, Nova Scotia, Canada, B4P 2R6

Introduction: Selective Estrogen Receptor Modulators or SERMs, are hormone therapy drugs used to combat hormone-positive breast cancers. Ideally, SERMs are antagonists in the breast tissue (limit and/or inhibit breast tumour growth), and agonists in other tissues of the body (carry out the essential functions of estrogen). Dr. Amitabh Jha and his team at Acadia have synthesized two novel 6-(4-Hydroxypiperidino)naphthalen-2-ol based SERMs that have shown potential in preliminary biological studies.

Methods: The mechanism of action of these drugs can be assessed through differential gene expression studies. Gene pathways of interest for these SERMs were assessed in Fundulus diaphanous, a fish species with many human protein-coding orthologs. RNA was extracted from gill tissue of fish treated with the various SERMs for quantitative PCR analysis.

Results: Elongation factor $\alpha$ was found to be a suitable reference gene, showing stable expression various treatments (DMSO, novel SERMs, 17- $\beta$ estradiol). Cyclin D1 showed significant upregulation for both novel SERMs and 17- $\beta$ estradiol. This upregulation at the six-hour time point was maintained through the 24-hour sampling period as well.

Conclusion: Analyzing the mechanism(s) of action for the SERMs can be useful as another biological assay for medicinal chemists in identifying potentially deleterious side effects and assessing efficacy.

Bat diet analysis using insect cuticular markers

Nathan T. McEwen, BSc Student [1], Christopher Buschhaus, PhD [1]

[1] Department of Biology, Crandall University, Moncton, New Brunswick, Canada E12G $3 H 9$

Bat prey consumption is difficult to quantify in the wild due to the speed and ferocity of prey capture. Current techniques for bat diet analysis are either unnecessarily invasive, expensive or time consuming. Fecal lipid analyses provide an alternative, non-invasive approach that has successfully been used for diet evaluation in domesticated herbivores. However, to date it has not been applied to insectivorous mammals. Here we present proof of concept that bat diet can be discerned through this process of fecal lipid analysis. Utilizing gas chromatography and mass spectrometry, the chemical fingerprint of insect-specific cuticular very-long-chain fatty acids was cross referenced with guano lipids to determine diet. Guano from captive big brown bats (Eptesicus fuscus) fed mealworms (Tenebrio spp.) had a lipid profile that closely correlated with the mealworm lipid profile. In contrast, guano from wild big brown bats displayed an entirely unique lipid signature. Based on this, further research cataloguing insect cuticular compositions should permit a fast and cost-effective means of ascertaining bat diet and dietary changes. This in turn will provide valuable insight for bat conservation measures.

Borrelia burgdorferi prevalence in three northwestern Nova Scotia counties Caitlin V. McGowan, BSc Student [1], Vett K. Lloyd, PhD [2]

[1] Department of Biology, Mount Allison University, Sackville, New Brunswick, Canada E4L 1E4

[2] Department of Biology, Mount Allison University, Sackville, New Brunswick, Canada E4L 1E4

Introduction: Frequent grazing in tick habitat leads cows in Nova Scotia to be susceptible of tick-vectored pathogens, such as Borrelia burgdorferi. However, the direct impact and associations of $B$. burgdorferi infection on these cows remains unknown. Methods: Serum from 100 outdoor grazing dairy cows from 5 different farms in Kings, Annapolis, and Hants counties Nova Scotia were collected and tested using enzyme-linked immunosorbent assay for antibodies to Borrelia burgdorferi.

Results: $80 \%$ of cattle showed seropositivity indicating exposure at some point in the cow's lifetime. Annapolis county had the highest incidence (85\%) while Hants county had the lowest (75\%). Cows were examined for 13 common signs associated with bovine Lyme disease. Of 80 seropositive cows, $13.8 \%$ exhibited signs associated with bovine Lyme disease in prior studies. Neither signs of disease nor age were significant indicators of seropositivity ( $\mathrm{p}=0.952$ and $\mathrm{p}=0.4495$ respectively).

Conclusion: Antibody titers do not indicate current infection, only past exposure so establishing correlation between signs observed and B. burgdorferi infection versus other diseases or infections would require direct detection of infection. The results of this study indicate that anti-B. burgdorferi antibodies are detectable in a high proportion of dairy cows in these regions of Nova Scotia. 
UNDERGRADUATE RESEARCH IN NATURAL AND CLINICAL SCIENCE AND TECHNOLOGY (URNCST) JOURNAL Read more URNCST Journal articles and submit your own today at: https://www.urncst.com

Stability of clonal lineages of killifish hybrids over time: A research study

Svetlana Tirbhowan, BSc Student [1], Lauren S. Johan, MSc Student [2], Anne C. Dalziel, Supervisor [3]

[1] Department of Biology, Saint Mary's University, Halifax, Nova Scotia, Canada, B3H 3C3

The majority of vertebrates reproduce sexually, but a small percentage can reproduce clonally (asexual reproduction). The Common Killifish (Fundulus heteroclitus) and Banded Killifish (Fundulus diaphanus) are found along the Atlantic coast of Canada and sympatric populations are able to hybridize and produce female clones. These clonal lineages have independently arisen multiple times throughout the Maritimes, and Porter's Lake, Nova Scotia, is the home of the best-studied population. Ten years earlier, ten clonal lineages were found and one major clone was dominant in Porter's Lake. As well, three sexuallyreproducing hybrids were detected and all hybrids had $F$. diaphanus mothers. The goals of my study are to: i) determine if the same major clone is still dominant in this site ten years later, ii) search for further evidence of sexually-reproducing hybrids, and iii) test if any hybrids have $F$. heteroclitus mothers. To do so, we are using a mitochondrial DNA restriction fragment length polymorphism assay to assess maternal lineages and four nuclear DNA microsatellites that vary among species to assign clonal lineages and test for sexually reproducing hybrids.

Evaluation of stress in horses during therapeutic riding sessions

Larissa Carr, BSc Honours Student [1], Laurie McDuffee, PhD [2], William Montelpare, PhD [3]

[1] Department of Biology, University of Prince Edward Island, Charlottetown, PE

[2] Atlantic Veterinary College, University of Prince Edward Island, Charlottetown, PE

[3] Applied Human Sciences, University of Prince Edward Island, Charlottetown, PE

In order to evaluate stress in horses during therapeutic riding sessions, observable behavioural indicators of stress, and physiological indicators of stress (heart rate variability measures and salivary cortisol concentrations) were obtained. Four JoyRiders therapeutic riding horses participated in an 8-week program to provide equine therapy for riders with developmental, physical, cognitive and psychosocial disabilities. The horses also participated in 4 control sessions where they were ridden by people without disabilities. Behavioural indicators of stress and heart rate variability were measured across three activities including baseline (standing in a stall), during mounting and dismounting. Saliva samples were collected, from each horse, at two time intervals (baseline and dismount). Mounting induced the highest number of stress-related behaviours across the 3 activities in both sessions. The mean number of stress-related behaviours during mounting was higher during therapeutic riding sessions compared to control sessions. The low frequency (LF)/high frequency (HF) ratio, an important heart rate variability measure, was higher during mounting in both therapy and control sessions, when compared to the baseline, and the LF/HF ratio for baseline and dismounting was higher in therapeutic riding compared to control sessions. There was no significant difference in cortisol levels between the horses' baseline activity and dismount, across both sessions. The results show that mounting induces stress during riding and this stress was greater during therapeutic riding sessions. In addition, the sympathetic nervous system increased during the therapeutic riding sessions indicating physiological stress, which was a higher change than that observed in the control sessions.

Faecal lipid analyses show that white-tailed deer primarily consume deciduous browse Maggie A.J. McEwen, BSc Student [1], Christopher Buschhaus, PhD [1] [1] Department of Biology, Crandall University, Moncton, New Brunswick, Canada E1G $3 H 9$

The effects of the silvicultural usage of glyphosate in New Brunswick, Canada on the amount of forage available to Odocoileus virginianus (white-tailed deer) has been a controversial issue in recent years. In this study we examined the diet of white-tailed deer in the province during the spring. Very-long-chain fatty acid derivatives from both deer faecal matter and the cuticles of their food sources were analyzed using gas chromatography and mass spectrometry. The wax coating deciduous browse was dominated by very-long-chain alkanes. In contrast, coniferous leaf waxes contained primarily a single very-long-chain secondary alcohol. This secondary alcohol was also found as a minor component in Malusand Prunus spp. waxes, together with its isomers. Analysis of deer faecal matter revealed very small quantities of the secondary alcohol, although, this compound was consistently associated with relatively high proportions of its isomers. This indicates the likely consumption of $M a$ lus and Prunus spp. but also suggests that $O$. virginianus do not consume coniferous needles as browse. Further research is required to determine diet composition over an entire year and thus shed light on the issue of glyphosate-spraying and whitetailed deer browse in New Brunswick.

Yang et al. | URNCST Journal (2019): Volume 3, Issue 4

DOI Link: https://doi.org/10.26685/urnest.142 
UNDERGRADUATE RESEARCH IN NATURAL AND CLINICAL SCIENCE AND TECHNOLOGY (URNCST) JOURNAL Read more URNCST Journal articles and submit your own today at: https://www.urncst.com

Using development functions to predict the development of American lobster (Homarus americanus) embryos in the Southern Gulf of St. Lawrence

Kaitlin R. Casey, BSc Student [1], Rémy Rochette, PhD [1]

[1] Department of Biology, University of New Brunswick, Saint John, New Brunswick, Canada E2L 4 L5

The ability to predict hatch time of American lobster larvae is important for understanding larval dispersal, as it affects the environmental conditions developing larvae experience and the connectivity between populations. A linear and exponential function were previously developed in laboratory to predict lobster embryonic development in relation to temperature. In this study, 12 embryos from 12 females were sampled on two occasions $\approx$ one month apart during the spring fishery at 13 sites in the Southern Gulf of St. Lawrence, and embryo development status was assessed on the basis of their eye size. The difference in average eye size between samples was taken as the "observed development" and compared to a "predicted development" which was based on the development functions and recorded bottom water temperature. There was higher variability in observed than predicted development among sites, and no relationship between the two values using either function. The inability of the functions to predict mean development at these sites could be due to shortcomings of the sampling procedure, measurement error, or geographic variation in temperature-based embryonic development rates that is not captured by the development functions. This study suggests that time-of-hatch predictions might be improved by assessing location specific development rates.

An examination of the impact of the freshwater mussel Elliptio complanata on water quality Victoria R. Field, BSc Student [1], Kellie White, Supervisor, BSc, MSc [1] [1] Department of Biology, Cape Breton University, Sydney, Nova Scotia, Canada B1P 6 L2

Pottle Lake is the drinking water source for the town of North Sydney and has the highest quality water within the Cape Breton Regional Municipality. It also serves as a refuge for an estimated 5.5 million freshwater mussels. These mussels may be contributing to the increased water quality in Pottle Lake. Each mussel filters $0.5-1 \mathrm{~L}$ of water every hour potentially "cleaning" the freshwater in the lake. The goal of this study was to examine the impact the freshwater mussel Elliptio complanata (the most common mussel species in Pottle Lake) has on water quality. To address this goal, I did a series of tank experiments examining how freshwater mussel filtration impacts metal, dissolved organic carbon (DOC), algae, and silt concentrations in water. It was observed that mussels significantly $(\mathrm{p}<0.05)$ reduced concentrations of the metals Al, Si and Mn. Mussels also significantly reduced silt and algal concentrations over time. No significant impact was observed for DOC. My results support the idea that the freshwater mussels are contributing to the high water quality of Pottle Lake and suggest that freshwater mussels like E. complanata provide valuable ecological services by filtering surface drinking water supplies.

Genomic insights into Nephromyces, a novel lineage of the Apicomplexa

Keira M. Durnin, BSc Student [1,2], Sergio A. Muñoz-Gómez, PhD Student [1,2], Laura Eme, PhD [3], Chris Paight, PhD [4], Chris E. Lane, PhD [4], Mary B. Saffo, PhD [5], Claudio H. Slamovits, PhD [1,2]

[1] Department of Biochemistry and Molecular Biology, Dalhousie University, Halifax, NS, Canada B3H 4 R2

[2] Centre for Comparative Genomics and Evolutionary Bioinformatics; Dalhousie University; Halifax, Nova Scotia, B3H 4R2; Canada

[3] Department of Cell and Molecular Biology, Science for Life Laboratory, Uppsala University, Uppsala, Sweden

[4] Department of Biological Sciences, University of Rhode Island, Kingston, RI 02881, USA

[5] Smithsonian National Museum of Natural History, Washington, DC 20560, USA

Nephromyces is a unicellular eukaryote (protist) found in the ductless renal sac organ of all molgulid tunicates (marine invertebrates from the phylum Chordata, commonly known as sea squirts). Although previously an enigma, using molecular data, Nephromyces was placed in Apicomplexa, a diverse phylum of obligate intracellular parasites, but its precise relationship with other apicomplexans is still unclear. To gain insight into the biology and evolution of Nephromyces, we sequenced total cDNA and DNA isolated from the renal sac of a molgulid individual and created metatranscriptomic and metagenomic datasets, respectively. In an inferred phylogenetic tree from ninety nuclear-encoded proteins, Nephromyces branched with the core apicomplexans, sister to the Hematozoa (haemosporidians and piroplasmids). We were able to recover and annotate thirteen apicoplast genomes demonstrating that the Nephromyces lineage has retained the apicoplast. Additionally, we identified plastid enzyme genes necessary for fatty acid, heme, and isoprenoid synthesis indicating that the apicoplast has retained biosynthetic

Yang et al. | URNCST Journal (2019): Volume 3, Issue 4

DOI Link: https://doi.org/10.26685/urnest.142 
UNDERGRADUATE RESEARCH IN NATURAL AND CLINICAL SCIENCE AND TECHNOLOGY (URNCST) JOURNAL Read more URNCST Journal articles and submit your own today at: https://www.urncst.com

pathways. Our results help us understand the nature of Nephromyces and the diversity in Apicomplexa. Moving forward, increased taxon sampling of Apicomplexa is required to further understand the evolution of Apicomplexa and shed light on the evolutionary impact of symbiosis.

The cytokine spätzle comparatively analyzed among Atlantic and Australian crustacean species Shae C. Scully, BSc Student [1], Fraser K. Clark, PhD [1,2]

[1] Department of Biology, Mount Allison University, Sackville, New Brunswick, Canada

E4L $1 E 2$

[2] Department of Animal Science and Aquaculture, University of Dalhousie, Bible Hill, Nova Scotia, Canada B3H 4 R2

Fisheries are highly susceptible to pathogen mediated destruction, with disease remaining one of the major limiting factors of aquaculture production. As crustacean aquaculture grows to accommodate the growing global demand, the importance of research into crustacean immunology also grows. The protein spätzle, which is involved in the toll and immunodeficiency pathways in crustaceans, was examined. Spätzle, being a cytokine, is an important molecule involved in cell signaling, specifically signaling in the innate immune system. The toll and immunodeficiency pathways are responsible for controlling the expression of most genes responsible for microbial immune response. The presence of spätzle isoforms was examined in several different species of crustaceans, with the aim of this project being to determine whether spätzle isoforms are more closely related across crab species, or if the isoforms will be comparable between crab and non-crab species. This information is important because a comprehensive understanding of crustacean immune response will result in the improvement of practices affecting crustacean health in aquaculture.

The effects of handling stress on cannabinoid receptors in mummichogs, Fundulous diaphanous Jack T. Guthrie, BScH Student [1], Russell Easy, PhD [1], Brian, Wilson, PhD [1]

[1] Department of Biology, Acadia University, Wolfville, Nova Scotia, Canada, B4P 2N9

Introduction: The endocannabinoid system is composed of protein receptors, enzymes, and lipid based neurotransmitters. The system is located within the central nervous system and peripheral organs in vertebrates, and is responsible for regulating many physiological and cognitive functions, including neural development, memory, anxiety and immune cell proliferation. Cannabis sativa, a commonly used recreational drug, is a ligand known to interact with the endocannabinoid system, inducing the psychoactive and medicinal effects seen in users. This project looks to examine how stress affects gene expression and protein synthesis of the two cannabinoid receptors, CB1 and CB2, in the brain and spleen of mummichogs (Fundulous diaphanous) following stress.

Methods: Mumichogs were exposed to a 30 second out of water handling stress, and sampled at 1, 6, and 24 hours following the stress. RNA was extracted from the brain and spleen and synthesized into cDNA, and protein was extracted from the brain. Quantitative real-time polymerase chain reaction (qPCR) was used to examine gene expression $c b l$ expression in the brain and $c b 2$ expression in the spleen. Western blotting was used to explore protein production in the brain.

Results: $C b 2$ was upregulated at 6 and 24 hours following exposure to stress, while $c b 1$ experienced an upregulation at 1 and 24 hours. CB2 production was consistent following stress, while CB1 production was arrested at 6 and 24 hours following the stress.

Conclusion: Handling stress induces changes in gene expression and protein production within the endocannabinoid system of mummichogs. Future directions include looking at the effects on the expression and production of cannabinoid receptors in response to cannabinoid exposure.

The effects of fasting on aspects of thermal tolerance (CTmax) in juvenile shortnose sturgeon (Acipenser brevirostrum) Allyson K. Cook, BSc Student [1], James D. Kieffer PhD [2,3]

[1] Department of Biology, University of New Brunswick, Saint John, New Brunswick, Canada E2L4L5

Sturgeon populations continue to decline primarily because of human activities including: damming of rivers (water diversion), over-fishing and climate change. Water diversion and climate change can affect the thermal profiles of the river, which can modify a species' food resources. Many studies on the stress response in sturgeon examine the impacts of a single stressor. The current study investigated the effects of food deprivation on the critical thermal tolerance (CTmax) and the physiology of shortnose sturgeon; the goal was to understand how fasting interacts with the physiological performance of sturgeon when challenged with a temperature stress. The critical thermal maximum (CTmax) and physiological responses of juvenile shortnose

Yang et al. | URNCST Journal (2019): Volume 3, Issue 4

Page A18 of A22

DOI Link: https://doi.org/10.26685/urnest.142 
UNDERGRADUATE RESEARCH IN NATURAL AND CLINICAL SCIENCE AND TECHNOLOGY (URNCST) JOURNAL Read more URNCST Journal articles and submit your own today at: https://www.urncst.com

sturgeon were investigated in shortnose sturgeon $(\sim 130 \mathrm{~g})$ fasted for one, three and seven days. CTmax did not change with increasing fasting levels (average CTmax across fasting times $\sim 30.5^{\circ} \mathrm{C}$ ). Levels of plasma glucose, lactate and osmolality significantly increased following thermal stress, but generally did not differ between different fasting periods. These findings suggest that sturgeon can tolerate thermal stress well; however, the mechanism involved in thermal tolerance likely is not related to nutritional status.

The reproductive biology of the deep-sea hairy snail, Alviniconcha hessleri Megan D. Warren, BSc Student [1], Suzanne C. Dufour, PhD [1], Amanda E. Bates PhD [2]

[1] Department of Biology, Memorial University of Newfoundland, St. John's, Newfoundland, A1B $3 X 9$

[2] Department of Ocean Sciences, Memorial University of Newfoundland, St. John's, Newfoundland, A1B $3 X 9$

Hydrothermal vents are unique habitats that support a dense marine biota in some of the harshest conditions on the planet. At western Pacific Ocean vents, one of the most abundant species by biomass is the hairy snail, Alviniconcha hessleri. This resilient mollusc lives in areas of high temperature, extreme pressure, and low $\mathrm{pH}$. The gills of $A$. hessleri have an enlarged surface area and host endosymbiotic chemosynthetic bacteria that supply most of the host's dietary needs. Despite their abundance, much of $A$. hessleri's life history is a mystery. Here, we examine the reproductive biology and population size structure of $A$. hessleri sampled from five vent sites and present observed trends in reproductive capacity and recruitment. Continuous development of oocytes suggests that these snails are capable of reproducing continuously; however, the size structure of the samples taken from different vents suggests that recruitment is periodic. We found no difference in the size of males and females and no evidence for sequential hermaphrodites, but noted that a few individuals appear to be simultaneous hermaphrodites. We propose that $A$. hessleri can reproduce continuously, but that harsh and variable conditions lead to limitations in recruitment success, resulting in different, site-specific population size structures.

Determining the anti-cancer potential of the anticancer peptide Mastoparan and its derivatives on HCT-116 colon cancer cells

Jacqueline T. Stevens, BSc Student [1] Wasundara Fernando, PhD [2], David W. Hoskin, PhD [2,3,4], Ashley L. Hilchie, PhD [1], Melanie R. Power-Coombs, PhD [1]

[1] Department of Biology, Acadia University, Wolfville, Nova Scotia, CA

[2] Department of Pathology, Dalhousie University, Halifax, Nova Scotia, CA

[3] Department of Microbiology, Immunology, Dalhousie University, Halifax, Nova Scotia, CA

[4] Department of Surgery, Dalhousie University, Halifax, Nova Scotia, CA

Anti-cancer peptides (ACPs) are small peptides that exhibit increased toxicity towards cancer cells. Mastoparan is an amidated venom peptide extracted from the wasp species Vespula lewissi. Mastoparan acts as a broad-spectrum ACP that possesses increased toxicity towards cancer cells compared to normal cells. With a single amino acid change from the parent peptide 4 derivatives of the peptide have been made: R7, S8W14, W1, G2. Here we report the anti-cancer effects of mastoparan and derivatives of mastoparan on the HCT-116 colon cancer cell line in vitro. Following treatment with mastoparan, it was found through a methylthiazolyldiphenyl-tetrazolium bromide (MTT) assay that HCT-116 cell metabolic activity decreased. Through flow cytometric analysis a decrease in cell viability and an increase in PI positive cells was also observed following treatment each ACP. ACP W14 demonstrated toxicity towards cancer cells at lower concentrations in comparison to other ACPs. Further understanding the mechanism by which mastoparan kills colon cancer cells and exploring the full ability of derivative W14 are of interest for future work.

Examining genetic differential expression of the Atlantic deep-sea scallop in the Northumberland Strait Kristena E. Daley, BSc Student [1], Monique M. Niles [2], Denise Méthé, PhD [2], K. Fraser Clark, PhD [1,3] [1] Department of Biology, Mount Allison University, Sackville, NB, Canada, E4L 1E2

[2] Department of Fisheries and Oceans, Gulf Fisheries Centre, Moncton, NB, Canada, E1C $9 B 6$

[3] Department of Animal Sciences and Aquaculture, Dalhousie University, Bible Hill, NS, Canada, B2N 4H5

Introduction: The Atlantic deep-sea scallop (Placopecten magellanicus) is an economically important bivalve found from Newfoundland, Canada to North Carolina, USA that contributes greatly to North American fisheries. In 2016, fishermen local to the Atlantic provinces of Canada noticed that scallops in West Point, PEI contained smaller adductor muscles than other scallops from the Southern Gulf of St. Lawrence.

Yang et al. | URNCST Journal (2019): Volume 3, Issue 4

DOI Link: https://doi.org/10.26685/urncst.142 
UNDERGRADUATE RESEARCH IN NATURAL AND CLINICAL SCIENCE AND TECHNOLOGY (URNCST) JOURNAL Read more URNCST Journal articles and submit your own today at: https://www.urncst.com

Methods: Concerned about the health of these scallops, the Department of Fisheries and Oceans collected samples from four different locations across the Northumberland Strait: West Point (PEI), Miminegash (PEI), Cape Tormentine (NB), and Pictou (NS). The following project uses RNA-seq bioinformatics to look at differential gene expression of the samples taken, examine if there are differences and determine what those specific differences are. Scallop samples were sequenced, a de novo transcriptome was assembled, functional annotation was performed, and results will be confirmed by reverse-transcriptase quantitative polymerase chain reactions (RT-qPCR).

Results: Current results show differentially expressed genes between all four populations, with the second highest amount of gene expression seen between West Point and Cape Tormentine. The largest number of differentially expressed genes are seen between Miminegash and Cape Tormentine.

Conclusion: This project examines toxicology, metabolism and immune function of the deep-sea scallops and will ultimately aid the Department of Fisheries and Oceans Canada in determining both the health status of local scallops as well as why the meat from one location is abnormally smaller than the rest.

Salinity tolerance of Halocladius variabilis (Diptera: Chironomidae) larvae from the rocky intertidal zone of Nova Scotia, Canada

Sydney M. Silver, BSc Student [1], Morley M. Mackinnon, Bsc Student [1], David M. Garbary, PhD [1], Michael M. CardinalAucoin, PhD [1]

[1] Department of Biology, St. Francis Xavier University, Antigonish, Nova Scotia, Canada B2G-2W5

The non-biting midge Halocladius variabilis inhabits the intertidal zone along temperate rocky shores where its larvae form a symbiotic relationship with the epiphytic fucoid algae, Elachista fucicola. H. variabilis larvae are among the few insects that have adapted to a marine environment, providing a unique opportunity to examine the osmoregulatory physiology of a marine insect and its contribution to the insect's distribution and ecology. Algae harbouring midge larvae were collected at Tor Bay, Guysborough County, NS, between July and August 2018. Larvae were sorted into groups of 10 and transferred to seawater concentrations of $0 \%$ (freshwater) to $270 \%$. Three replicates were performed at each concentration. Larvae were maintained at $15^{\circ} \mathrm{C}$ with a $12 \mathrm{~h}: 12 \mathrm{~h}$ light:dark cycle and survival monitored over 12 days. Two-way ANOVA and post hoc analyses revealed a salinity tolerance from $50 \%$ to $200 \%$ seawater, which differs from that of related marine species in which this has been studied. Preliminary immunohistochemical investigations showed differences in the distribution of two major ion channels in osmoregulatory tissues of $H$. variabilis compared to the freshwater midge Chironomus riparius. These results indicate that $H$. variabilis is well-suited to its variable intertidal habitat and suggest that different midge species employ different physiological osmoregulatory strategies.

Is claudin 10 expression associated with hyper-salinity tolerance in Killifish (Fundulus spp.)?

Adelaide M. von Kursell, BSc Student [1], Lauren S. Jonah, MSc Student [1], Anne C. Dalziel, Supervisor [1]

[1] Department of Biology, Saint Mary's University, Halifax, NS, Canada, B3H 3C3

To survive, fish must maintain ionoregulatory and osmoregulatory homeostasis during changes in environmental salinity. In hypersaline water, fish must actively excrete salts and drink water to counterbalance the passive influx of salts and efflux of water. Excess sodium ions are excreted through paracellular pathways, and the claudin proteins are core tight junction components that influence paracellular ion permeabilities. It is predicted that claudin isoform switching in osmoregulatory epithelia is critical for fish salinity acclimation. However, it is not known if the evolution of claudin structure or expression leads to differences in salinity tolerance among species of fishes. To study this question, we are comparing claudin isoform expression in the opercular epithelia of killifishes. The Common Killifish (Fundulus heteroclitus) can tolerate salinities far exceeding that of full strength seawater and expresses a unique subset of claudin 10 isoforms in hypersaline conditions. The Common Killifish interbreeds with sympatric Banded Killifish (Fundulus diaphanus), a species that is less tolerant to high salinities, forming viable hybrid offspring. We have found that Banded Killifish and hybrids are less tolerant to high salinities and are currently testing if this is associated with changes in claudin 10 isoform structure and expression in the operculum and gill.

Yang et al. | URNCST Journal (2019): Volume 3, Issue 4

DOI Link: https://doi.org/10.26685/urnest.142 
UNDERGRADUATE RESEARCH IN NATURAL AND CLINICAL SCIENCE AND TECHNOLOGY (URNCST) JOURNAL

Read more URNCST Journal articles and submit your own today at: https://www.urncst.com

Development of a habitat suitability index to identify new populations of the brook floater mussel (Alasmidonta varicosa) in Cape Breton

Julia Elizabeth Cameron, BSc Biology [1], Psychology student, Kellie White, MSc [2]

[1]Department of Biology, Cape Breton University, Sydney, Nova Scotia, Canada, B1P 6L2

Brook floater (Alasmidonta varicosa) is a rare freshwater mussel species of "Special Concern" in Canada and is only known to occur in a small number of streams in NB and NS. My objective was to identify habitat characteristics associated with this species. I examined mussel literature and identified the following variables as potential indicators of brook floater habitat quality: stream gradient, stream order, stream catchment size, stream width, distance from estuary, and bedrock geology. I measured these variable using maps, satellite imagery and GIS for all sites containing brook floater in NB and NS. Presence of other mussel species was also recorded for each site based. Streams supporting brook floater were found to be highly variable in relation to most measured variables. However, stream gradient, which is associated with substrate stability, was low to moderate and two other mussel species (Eastern Elliptio and Freshwater Pearls) were present in the majority of brook floater streams. These variables may provide useful indicators of streams that would support brook floater. This information will be used to identify potential brook floater streams in Cape Breton that could be targeted for live searches and eDNA sampling.

\title{
Conflicts of Interest
}

The author(s) declare that they have no conflict of interests.

\section{Authors' Contributions}

ZY: served as the conference coordinator of Science Atlantic Aquaculture \& Fisheries and Biology Conference 2019, drafted the conference abstract booklet, and gave final approval of the version to be published.

RHE: served as the president of Science Atlantic Biology committee, assisted authors with their abstract submissions, and gave final approval of the version to be published.

\section{Acknowledgements}

We would like to thank all of our generous sponsors, which are listed in the section of Funding as below. Here we also would like to thank Michelle McPherson, Program and Membership Support Officer, for providing great help and advice.

\author{
Funding \\ Crandall University VP of Academic \\ CU Biology Faculty \\ Benson Aquaculture \\ Canadian Botanical Association \\ Agricultural Alliance of NB \\ Fisheries \& Marine Institute, MUN \\ Ocean Frontier Institute \\ Newfoundland Aquaculture Industry Association \\ Elanco
}

\author{
Science Atlantic \\ NSCC \\ Agricultural Alliance of NB \\ City of Moncton \\ Aquaculture Association of Canada \\ Miramichi Striper Club \\ Cooke Aquaculture Inc. \\ Coastal Zones Research Institute Inc.
}

\author{
Article Information \\ Managing Editor: Jeremy Y. Ng \\ Article Dates: Received Mar 15 19; Published Apr 1819

\section{Citation} \\ Please cite this article as follows: \\ Yang Z, Easy RH. Science Atlantic 2019 Aquaculture \& Fisheries and Biology Conference. URNCST Journal. 2019 Apr 18 : \\ 3(4). https://urncst.com/index.php/urncst/article/view/142 \\ DOI Link: https://doi.org/10.26685/urncst.142
}




\section{Copyright}

(C) Zhan Yang, Russell H. Easy (2019). Published first in the Undergraduate Research in Natural and Clinical Science and Technology (URNCST) Journal. This is an open access article distributed under the terms of the Creative Commons Attribution License (https://creativecommons.org/licenses/by/4.0/), which permits unrestricted use, distribution, and reproduction in any medium, provided the original work, first published in the Undergraduate Research in Natural and Clinical Science and Technology (URNCST) Journal, is properly cited. The complete bibliographic information, a link to the original publication on http://www.urncst.com, as well as this copyright and license information must be included.

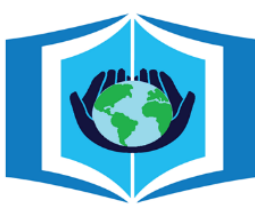

\section{URNCST Journal \\ "Research in Earnest"}

\section{Funded by the Government of Canada}

Canadà̀

Do you research in earnest? Submit your next undergraduate research article to the URNCST Journal!

| Open Access | Peer-Reviewed | Rapid Turnaround Time | International | | Broad and Multidisciplinary | Indexed | Innovative | Social Media Promoted |

Pre-submission inquiries? Send us an email at info@urncst.com | Facebook, Twitter and LinkedIn: @URNCST

Submit YOUR manuscript today at https://www.urncst.com!
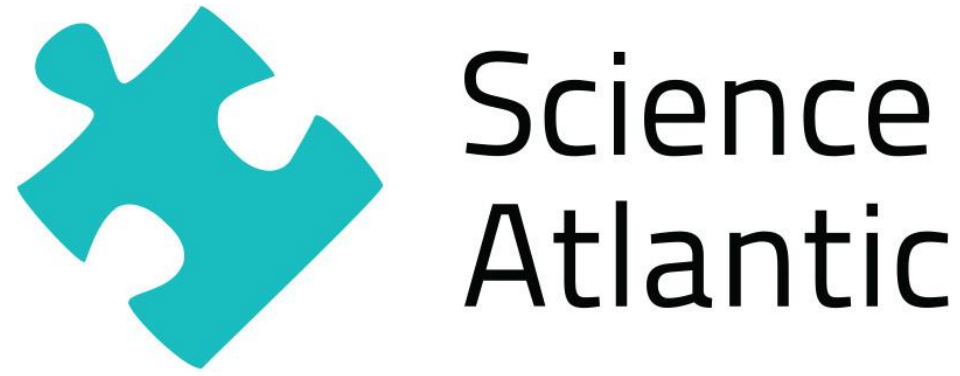

Science Atlantique 